\title{
Developing a vaccine for African trypanosomiasis: only wishful thinking or a definite possibility? Joana Carvalho ${ }^{1,2}$, Gabriel A Monteiro ${ }^{1}$, Jorge Atouguia3 ${ }^{3}$ Duarte Miguel F Prazeres ${ }^{1}$ and Jean Rodgers*2
}

\author{
Address: ${ }^{1} \mathrm{IBB}$, Institute for Biotechnology and Bioengineering, Centre for Biological and Chemical Engineering, Instituto Superior Técnico, 1049 - \\ 001 Lisbon, Portugal, ${ }^{2}$ Division of Infection and Immunity, University of Glasgow Veterinary School, Glasgow, G61 1QH, UK and ${ }^{3}$ Instituto de \\ Higiene e Medicina Tropical, Universidade Nova de Lisboa, 1349-008 Lisbon, Portugal \\ Email: Jean Rodgers* - Jean.Rodgers@vet.gla.ac.uk \\ * Corresponding author
}

from Infectious diseases of the nervous system: pathogenesis and worldwide impact

Paris, France. 10-13 September 2008

Published: 23 September 2008

BMC Proceedings 2008, 2(Suppl I):P9

This abstract is available from: http://www.biomedcentral.com/I753-656I/2/SI/P9

(C) 2008 Carvalho et al; licensee BioMed Central Ltd.

African trypanosomiasis is an emergent disease with significant social and economical impact in 36 African countries. Available drug regimens are very limited and highly toxic so the development of a vaccine would be extremely advantageous. Since the parasite has the ability of misleading the immune response through antigenic variation of its surface coat the development of vaccine was thought to be highly unlikely. However research focused on the identification of invariant components to be used as therapeutic targets and the evolution of DNA vaccine technology bring this objective into the realms of possibility.

Ten DNA vaccine prototypes were constructed encoding ISG (invariant surface glycoprotein) and TSA (trans-sialidase) genes from Trypanosoma brucei. These were linked to different targeting sequences to direct the protein to the major antigen processing pathways: (1) LAMP-1 signal targets the protein to the lysosomes (pISGlamp, pTSAlamp); (2) E1A directs the protein to the ER (pe1aISG, pe1aTSA) (3) secretion signal promotes protein secretion (pscISG, pscTSA) (4) E1A and LAMP combined (pe1aISGlamp, pe1aTSAlamp).

The candidate vaccines were tested alongside two controls (PBS and pVAX1GFP). Groups of six CD1 female mice were immunised $50 \mu \mathrm{g}$ DNA (or control) by intramuscular injection. Animals were killed 28 days post-immuniza- tion and the right popliteal and axillary lymph-nodes removed for mRNA extraction and histological analysis. In a second experiment the delayed hypersensitivity response (DTH) to trypanosome lysate was assessed. At 14 days post immunization mice mice were injected with 25 $\mu \mathrm{g}$ of trypanosome lysate into the right footpad. The contralateral footpad was injected with $25 \mu \mathrm{l}$ saline. Footpad thickness was measured at 0,24 and 48 hours after injection.

The expression of IFN- $\gamma$, TNF- $\alpha$, IL-1 $\beta$, IL-2, IL-4, IL-10 and IL-6 in lymphoid tissue was assessed using reverse transcriptase-PCR analyses. Expression levels were applied to rank the candidate vaccines on a scale of $1-12,1$ being the lowest and 12 the highest expression; pe1aISG, pISGlamp, pTSAlamp and pe1aISGlamp groups obtained the best scores. DTH analysis revealed an increase in footpad thickness in mice immunised with all ISG plasmids, pTSA, pscTSA and pelaTSA compared to PBS.

Histological analysis was used to determine the degree of activation present within the lymph-nodes. pISGlamp and pe1aISGlamp were found to induce the highest levels of stimulation.

On the basis of these experiments pISGlamp, pe1aISGlamp, pe1aISG and pTSAlamp were selected as 
the most promising vaccines. Challenge assays will determine their effect on progression of the disease.

Publish with Bio Med Central and every scientist can read your work free of charge

"BioMed Central will be the most significant development for disseminating the results of biomedical research in our lifetime. " Sir Paul Nurse, Cancer Research UK

Your research papers will be:

- available free of charge to the entire biomedical community

- peer reviewed and published immediately upon acceptance

- cited in PubMed and archived on PubMed Central

- yours - you keep the copyright 